\title{
EARLY DETECTION OF INJURIES IN LEAVES OF Clusia hilariana Schltdl. (Clusiaceae) CAUSED BY PARTICULATE DEPOSITION OF IRON ${ }^{1}$
}

Diego Ismael Rocha ${ }^{2}$, Luzimar Campos da Silva ${ }^{3}$, Eduardo Gusmão Pereira ${ }^{4}$, Bruno Francisco Sant'AnnaSantos $^{5}$, Elisa Rodrigues Gontijo ${ }^{6}$ e Marco Antônio Oliva ${ }^{3}$

\begin{abstract}
This study aims to evaluate the prognostic value of microscopic parameters of asymptomatic leaves of Clusia hilariana Schltdl. subjected to particulate deposition of iron $\left(2.14 \mathrm{mg} \mathrm{cm}^{-2} \mathrm{day}^{-1}\right)$ for 45 consecutive days. Samples of young and expanded leaves without symptoms were collected and subjected to light and scanning electron microscopy techniques. The height of the epidermal cells on both surfaces of the leaf and the thickness of the hypodermis, the chlorophyll parenchyma, and the leaf blade were measured. Micromorphological injury occurred in the abaxial surface of young leaves and on both surfaces of expanded leaves. Erosion of the epicuticular wax and cuticle rupture were frequent on the adaxial surface, while on the abaxial surface of both leaves there was a loss of sinuosity on the anticlinal wall of the epidermal cells, stomatal deformity and obstruction. Micromorphometric alterations were seen in all leaf tissues except in the height of epidermic cells, probably due to the thick cuticle and prominent cuticular flanges. The highest difference in thickness of the leaf blade was seen in young leaves of plants subjected to SPMFe, indicating greater sensibility to particulate iron in comparison to the expanded leaves. The micromorphological and micromorphometric alterations in the leaf blade of Clusia hilariana Schltdl. showed the prognostic potential of these tools on the evaluation of impacts caused by the deposition of particulate matter, especially in the 'Restinga' natural vegetation, where the exposure is increasing due to the presence of iron ore industry in their surroundings.
\end{abstract}

Keywords: Atmospheric pollution; Leaf anatomy; Restinga.

\section{DETECÇÃO PRECOCE DE INJÚRIAS EM FOLHAS DE Clusia hilariana Schltdl. (Clusiaceae) CAUSADAS PELA DEPOSIÇÃO PARTICULADA DE FERRO}

RESUMO - Avaliou-se o potencial prognóstico de parâmetros microscópicos de folhas assintomáticas de Clusia hilariana Schltdl. expostas à deposição particulada de ferro $\left(2.14 \mathrm{mg} \mathrm{cm}^{2}\right.$ dia-1), por 45 dias consecutivos. Amostras de folhas jovens e expandidas sem sintomas foram coletadas e submetidas a técnicas usuais em microscopia de luz e eletrônica de varredura. Foram mensurados a altura das células epidérmicas de ambas as faces da folha e a espessura da hipoderme, do parênquima clorofiliano e da lâmina foliar. Danos micromorfológicos ocorreram na superfície abaxial de folhas jovens e em ambas as faces de folhas expandidas. Erosão da cera epicuticular e ruptura cuticular foram frequentes na face adaxial, enquanto na face abaxial, de ambas as folhas, houve perda da sinuosidade da parede anticlinal das células epidérmicas, deformação e obstrução estomática. Alterações micromorfométricas foram observadas em todos os tecidos foliares, exceto na altura das células epidérmicas em razão, provavelmente, da espessa cutícula e flanges cuticulares proeminentes. A maior diferença na espessura da lâmina foliar foi verificada nas folhas jovens de plantas expostas à SPM ${ }_{F e}$, indicando maior sensibilidade ao ferro particulado em comparação com as folhas expandidas. As alterações

\footnotetext{
${ }^{1}$ Recebido em 05.12.2012 aceito para publicação em 09.04.2014.

${ }^{2}$ Programa de Pós-Graduação em Botânica, Universidade Federal de Viçosa, Viçosa, MG, Brasil. E-mail: <diegoirocha@gmail.com>

${ }^{3}$ Departamento de Biologia Vegetal, Universidade Federal de Viçosa, Viçosa, MG, Brasil. E-mail: <luzimar@ufv.br $>$ e $<$ moliva@ufv.br>

${ }^{4}$ Instituto de Ciências Biológicas e da Saúde, Universidade Federal de Viçosa, Campus Florestal, Florestal, MG, Brasil. E-mail: <egpereira@ufv.br>

${ }^{5}$ Instituto de Ciências Agrárias, Universidade Federal de Minas Gerais, Campus Regional Montes Claros, Montes Claros, MG, Brasil. E-mail: <brunoufv@yahoo.com.br>

${ }^{6}$ Graduada em Ciências Biológicas, Universidade Federal de Uberlândia, Uberlândia, MG, Brasil. E-mail: <elisagontijo@gmail.com>
} 
micromorfológicas e micromorfométricas observadas na lâmina foliar de Clusia hilariana Schltdl. demonstraram o potencial prognóstico dessas ferramentas na avaliação de impactos causados pela deposição de particulados, em especial na vegetação natural de restinga, onde a exposição é crescente diante da expansão de usinas mineradoras implantadas em sua vizinhança.

Palavras-chave: Poluição atmosférica; Anatomia foliar; Restinga.

\section{INTRODUCTION}

Emission of atmospheric pollutants by the iron mining industry has altered the structure, dynamics, and diversity of shoreline ecosystems on the Brazilian coast. In the State of Espírito Santo, Brazil, pelletizing industries, responsible for the extraction and processing of iron ores, were set up and are currently under steady expansion in the surrounding areas of the Restinga vegetation, a permanent preservation ecosystem (CONAMA, 1992).The pelletizing industries are sources of iron ore solid particulate matter $\left(\mathrm{SPM}_{\mathrm{Fe}}\right)$ in suspension; its deposite on the vegetation may affect its growth and the development of sensitive species or even their survival (GRANTZ et al., 2003; KUKI et al., 2008a). The reduction or elimination of entire populations can decrease the local biodiversity, and the regeneration capacity of the ecosystem (GRANTZ et al., 2003; KUKI et al., 2008a).

In plant species, the toxicity by iron can be of two types: direct toxicity, caused by the accumulation of high levels of iron in the plant tissues (OLALEYE et al., 2001; SILVEIRA et al., 2007), and indirect toxicity, caused by multiple nutritional disorder resulting from deposition iron-shaped plate in the roots (LIU et al., 2008; SIQUEIRA-SILVA et al., 2012).

The deposition of particulate matter on the leaf surface causes blockage of solar radiation by shadowing the leaf surface, altering the pigment synthesis, and the photosynthetic rate (HIRANO et al., 1995; NAIDOO; CHIRKOOT, 2004; OLIVEIRA et al., 2007; KUKI et al., 2008b; PEREIRA et al., 2009). Additionally, the obstruction of the stoma may cause the increase of the leaf temperature, the alteration of the transpiratory rate (PEREIRA et al., 2009) and anatomical and ultrastructural modifications in leaf tissues organization (SILVA et al., 2006).

Symptomatological, physiological, and biochemical parameters have been often used to evaluate the effects of the SPM $\mathrm{Fe}_{\mathrm{Fe}}$ deposition on plant species (LOPES et al., 2000; OLIVEIRA et al., 2007; KUKI et al. 2008a,b;
NEVES et al., 2009; PEREIRA et al., 2009). However, little attention has been paid to the prognostic value of microscopic parameters. Some species may accumulate high concentrations of pollutants and exhibit tissue injuries, although do not show visual damage (ARNDT et al., 1995). Micromorphological and micromorphometric analyses may help in the early detection of injuries, before visible symptoms start appearing (SODA et al., 2000; SANT'ANNA-SANTOS et al., 2007, 2012).

The morphoanatomical structure of leaves from species subjected to $\mathrm{SPM}_{\mathrm{Fe}}$ can contribute to the determination of their susceptibility to pollutants (PALING et al., 2001; SILVAet al., 2006). Characters of the epidermis, epicuticular wax deposition pattern, cuticle topography, epidermic cells shape, stomata distribution and position in relation to the other epidermal cells, are among the parameters involved in the plant responses to pollutants (SILVA et al., 2005; SANT'ANNA-SANTOS etal., 2006a,b, 2007; BALASOORIYA et al., 2009; KARDEL et al., 2010; RAÍ et al., 2010; MESQUITA et al., 2011).

Clusia hilariana Schltdl. (Clusiaceae) is a wood species commonly found in Brazilian Restinga (DIAS et al., 2006). They have great phytosociological importance, acting as a facilitator species in the processes of succession (DIAS et al., 2006). In previous studies, asymptomatic leaves of this species showed physiological alterations in response to the $\mathrm{SPM}_{\mathrm{Fe}}$ deposition, such as reduction of the pigment levels, compromising of the photosynthetic processes, and the increase of the leaf iron level (PEREIRA et al., 2009). Among possible causes, the authors have suggested it was due to the obstruction of the stoma and the iron absorption of the iron at leaf level, as the soil was covered during the $\mathrm{SPM}_{\mathrm{Fe}}$ applications (PEREIRA et al., 2009). However, the leaf structural and micromorphological analyses can be the key for answering these questions. The integration of morphoanatomical studies and the ecophysiological unravels the precise responses of plants species to the particulate iron deposition. 
Given the importance of morphoanatomical studies for the understanding of plants responses to particulate iron deposition, the aim of this paper is to evaluate the prognostic value of microscopic parameters by characterizing the micromorphological structure of asymptomatic C. hilariana leaves subjected to iron particulate deposition.

\section{MATERIALAND METHODS}

Clusia hilariana Schltdl. (Clusiaceae) plants were produced by means of cuttings from a single plant provided by the nursery of the Parque Estadual Paulo César Vinha, Guarapari, Espírito Santo, Brazil (20 40' 00" S, 40²9' 51" W). The seedlings were cultivated in Hoagland nutrition solution (HOAGLAND; ARNON, 1950), at half ionic strength at $5.5 \mathrm{pH}$. After rooting, they were transplanted into $5 \mathrm{~L}$ pots containing a mixture of soil, sand, and organic matter (2:2:1). Seedlings were acclimated to these conditions for three months.

The simulation experiment was performed in a greenhouse (average annual temperature of $27.6^{\circ} \mathrm{C}$; average relative humidity of $72 \%$ ) at the Universidade Federal de Viçosa (UFV) (2045'20” S, 42 52 ' 40”'W), by means of a chamber that create natural ore deposition, as proposed by Hirano et al., (1995), and modified by Pereira et al., (2009). Before the simulation, C. hilariana plants were standardized regarding their height uniformity, number of leaves, and phytosanitary state. The bases of the pots were covered with plastic film, leaving only the areal part subjected to the simulated deposition of iron solid particulate matter $\left(\mathrm{SPM}_{\mathrm{Fe}}\right)$. The experiment lasted 45 days, and the deposition simulation was performed at 8:00 in the morning. Inside the chamber, the amount of particulate matter deposited on the plants reached an average of $2.14 \mathrm{mg} \mathrm{cm}^{-2}$ day $^{-1}$ (PEREIRA et al., 2009). In the control treatment, the plants were not subjected to deposition of iron particulate. At the end of the experiment, the leaves from both control and SPM treatments were rinsed in distilled water and samples from the median section of young leaves $\left(1^{\text {st }} \mathrm{knot}\right.$ from the apical bud $)$ and fully expanded $\left(5^{\text {th }}\right.$ knot from the apical bud) were collected for the microscopic studies. Samples subjected to the iron treatment were taken from asymptomatic leaves (without any apparent injury).

For the scanning electron microscopy analysis, the collected samples were fixed in a solution containing glutaraldehyde $(2.5 \%)$, paraformaldehyde $(4 \%)$ in sodium cacodylate buffer 0.1M, pH 7.2 (KARNOVSKY, 1965).
The samples were rinsed in the same buffer, dehydrated, and stored in ethanol 70\%. After dehydration in ethylic series, the material was dried to critical point (CPD030, Bal-Tec, Balzers, Liechtenstein), fixed in stubs, and coated with gold (Sputter Coater FDU010, Bal-Tec, Balzers, Liechtenstein). The investigation and documentation were made in a scanning electron microscope (Leo 1430VP, Zeiss, Heidelberg, Germany) at the UFV.

For the anatomical characterization, the collected samples were fixed in $\mathrm{FAA}_{50}$ (formaldehyde, acetic acid and ethylic alcohol 50\%, 1:1:18 v/v) (JOHANSEN, 1940), dehydrated in ethylic series, and embedded in methacrylate (Historesin, Leica Instruments, Heidelberg, Germany). Transversal section at $6 \mu \mathrm{m}$ thick were made in an automatic rotary microtome (Leica RM 2155, Leica, Deerfield, IL, USA), stained with toluidine blue $\mathrm{pH}$ 7.2 (O'BRIEN; MCCULLY, 1981), and mounted in Permount. Image capturing was made in a photomicroscope (AX70TRF, Olympus Optical, Tokyo, Japan) equipped with a U-Photo system.

For the micromorphometric analyses, the height of the epidermal cells of both adaxial and abaxial surfaces, the leaf blade, the chlorophyll parenchyma, and the hypodermis of C. hilariana leaves were measured using the Image Pro-Plus version 4.1 (Media Cybernetics, Silver Spring, MD, USA) software. The five parameters were measured three times per cutting and fifteen cuts for each repetition $(n=4)$ of the conditions (control and $\mathrm{SPM}_{\mathrm{Fe}}$ ) were assessed, summing up 1,800 records.

The experimental delineation was completely randomized with two treatments $\left(\mathrm{SPM}_{\mathrm{Fe}}\right.$ and Control) and four repetitions per treatment. The data was subjected to analysis of variance (ANOVA) employing GENES software. Averages were compared by the Tukey Test with significance level set at $5 \%$.

\section{RESULTS}

Micromorphological injury to the epidermis of both surfaces of the expanded leaves and abaxial surface in young leaves was observed in plants exposed to iron ore solid particulate matter $\left(\mathrm{SPM}_{\mathrm{Fe}}\right)$.

For the control treatment, it was seen that the epidermis of the adaxial surface of C. hilariana is glabrous, with ordinary cells with defined shape and smooth epicuticular wax (Fig. 1A). In the plants subjected to the $\mathrm{SPM}_{\mathrm{Fe}}$ there was erosion of the epicuticular wax and cuticle rupture (Fig. 1B).

Revista Árvore, Viçosa-MG, v.38, n.3, p.423-432, 2014 

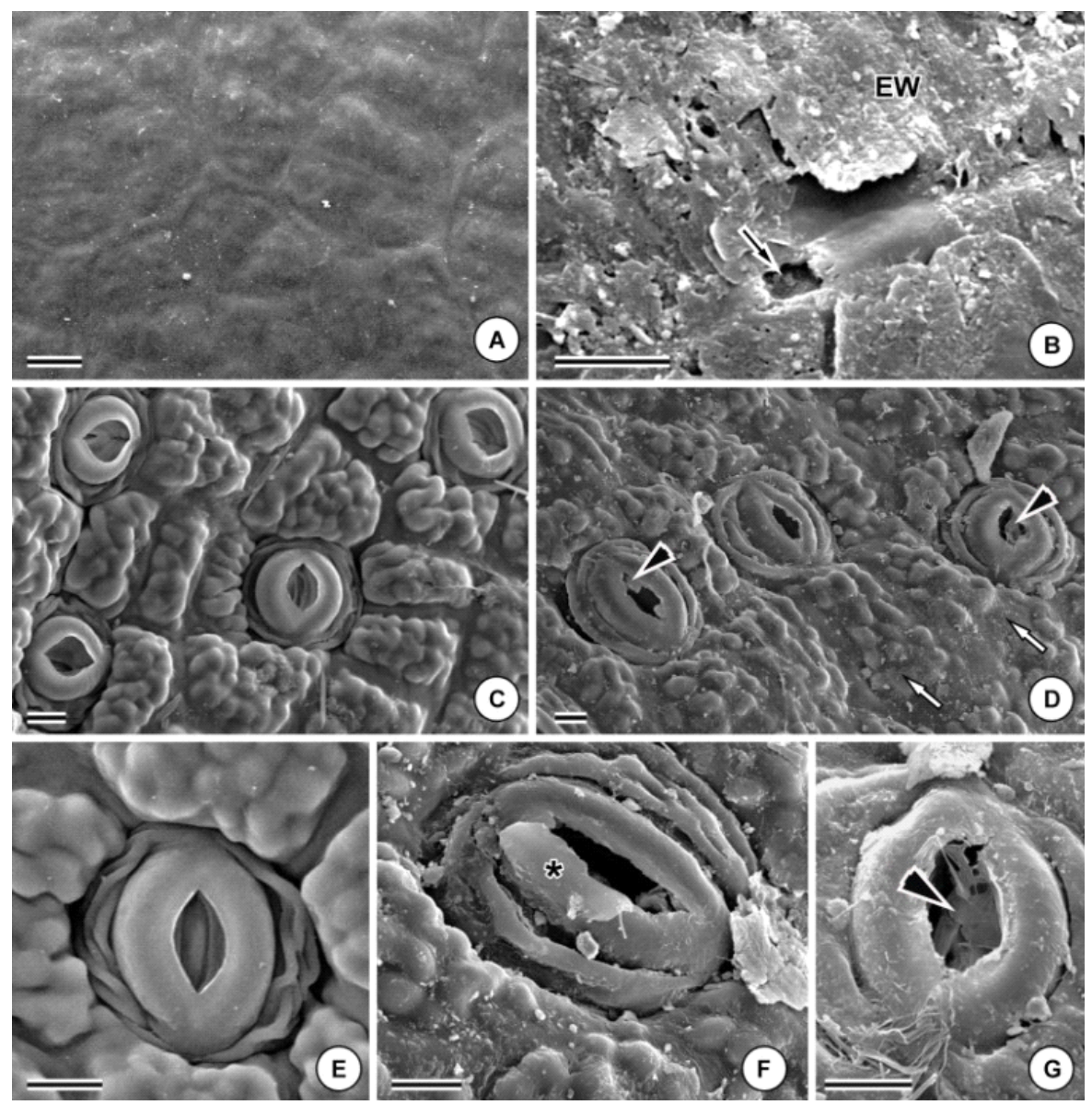

Figure 1 - Leaf surface of Clusia hilariana (scanning electron microscope) in the control treatment (A, C, E) and subjected to deposition of particulate iron (B, D, F, G). Adaxial surface of expanded leaves (A-B). (A) Distinct outline of the anticlinal walls. (B) Erosion of the epicuticular wax (EW) and cuticular rupture (arrow). Abaxial surface of young leaves (C-E, G) and of expanded leaves (F). (C) Distinct outline of the anticlinal walls. (D) Injuried and obstructed stoma ( $(\mathbf{)}$ ) and alterations in the outline of the cells' anticlinal walls (white arrows). (E) Stoma with intact stomatal ledges. (f) Stoma with deformed stomatal ledges (*). (g) Deformed stoma with obstructed superstomatal chamber $(\triangleright)$. Bars $=10 \mu \mathrm{m}$.

Figura 1 - Superfície foliar de Clusia hilariana (microscopia eletrônica de varredura) no tratamento-controle (A, C, E) e exposta à deposição de ferro particulado $(B, D, F, G)$. Face adaxial de folhas expandidas (A-B). (A) Contorno nítido das paredes anticlinais. (B) Erosão da cera epicuticular (EW) e ruptura cuticular (seta). Face abaxial de folhas jovens $(C-E, G)$ e de folhas expandidas $(F)$. (C) Contorno nítido das paredes anticlinais. (D) Estômatos danificados e obstruídos ( ) e alterações no contorno das paredes anticlinais das células (setas branca). (E) Estômato com crista estomática intacta. (f) Estômato com crista estomática deformada $\left(^{*}\right)$. (g) Estômato deformado com câmara superestomática obstruída (ヤ). Barras $=10 \mu \mathrm{m}$.

On the abaxial surface of young and expanded leaves, besides the erosion of the epicuticular wax, alterations on the relief of epidermic cells, with loss of sinuosity of the anticlinal walls (Fig. 1D), visually marked in the control treatment (Fig. 1C) were also observed. Lower turgidity of the guard cells resulted in the increase of furrows between them and the subsidiary cells (Fig. 1F), rupture of the stomatal ledges (Fig. 1D, F e G) and obstructions of the superstomatal chambers (Fig. 1D e G).

In the transversal section, no qualitative differences were seen between the leaves subjected and non-subjected to particulate deposition. The leaf blade of C. hilariana 
Early detection of injuries in leaves of clusia hilariana...

is made up of a uniserial epidermis with a thick cuticle, and cuticular projections at the anticlinal walls of the epidermis, constituting cuticular flanges on both leaf surfaces (Figs. 2A-C). The leaf is hypostomatal and the guard cells have prominent stomatal ledges (Figs. $2 \mathrm{~A}$ e C). The hypodermis is made up of three layers of cells which are compactly arranged on only the adaxial surface of the leaf(Fig. 2B). The leaf blade of C. hilariana is dorsiventral, with chlorophyll parenchyma having six to eight layers of palisade parenchyma and 12 to 15 layers of spongy parenchyma (Fig. 2A). Secretory channels and idioblasts with druse inclusions are found throughout all the mesophyll (Fig. 2B).
The deposition of $\mathrm{SPM}_{\mathrm{Fe}}$ in asymptomatic leaves of C. hilariana had a significant effect on the quantitative parameters evaluated, except on the height of the epidermic cell of both surfaces.

In the plants subjected to $\mathrm{SPM}_{\mathrm{Fe}}$, there was a significant reduction in the height of the hypodermis and the chlorophyll parenchyma of young leaves and expanded leaves (Tab. 1). There was also a significant reduction in the height of the leaf blade of young and expanded leaves (17.81\% and 10.72\%, respectively) of plants subjected to $\mathrm{SPM}_{\mathrm{Fe}}$ (Tab. 1, Fig. 3).
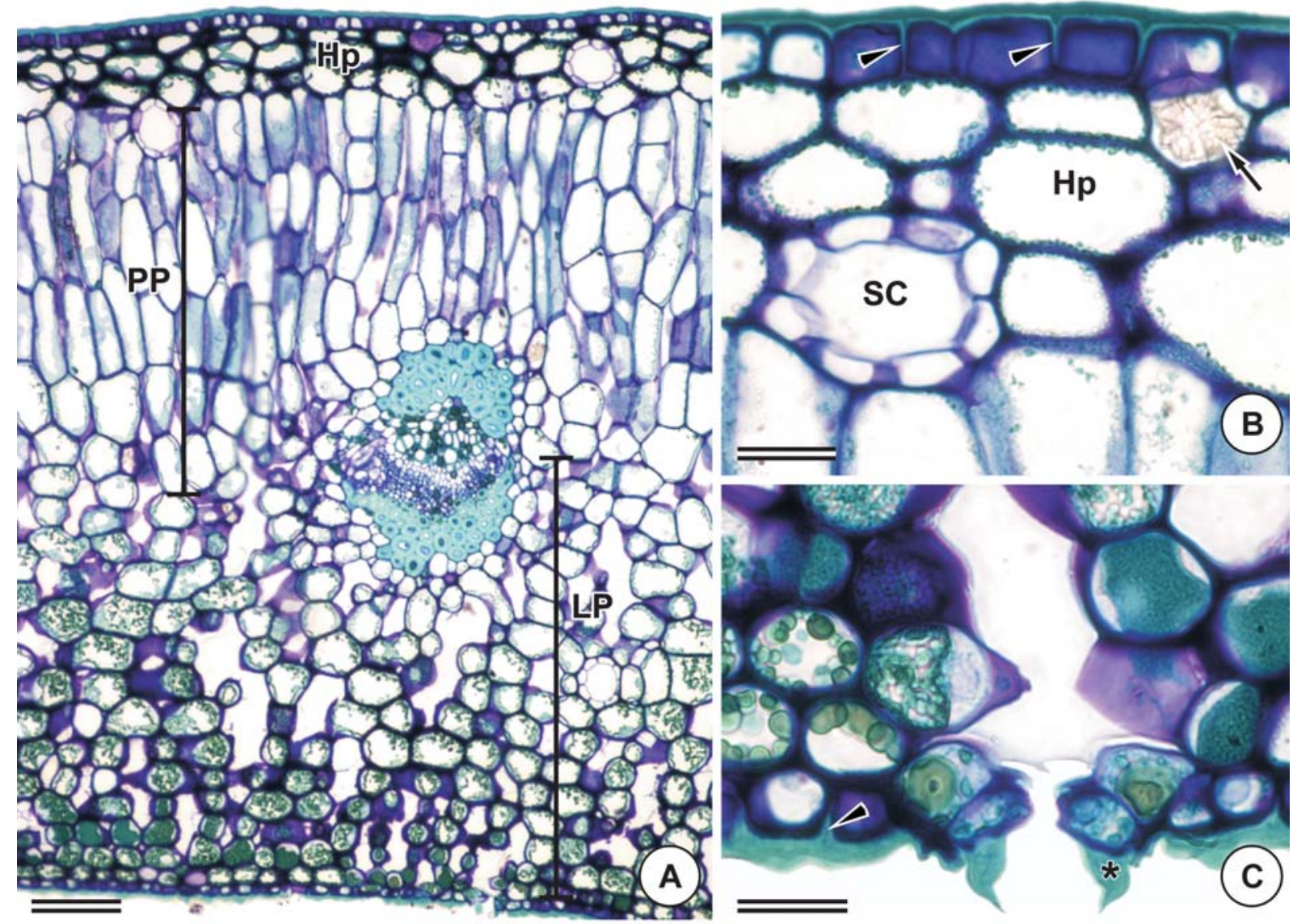

Figure 2 - Leaf structure of Clusia hilariana Schltdl., of control treatment plants, in transversal section. (A) General aspect showing the dorsiventral mesophyll. Bar $=100 \mu \mathrm{m}$. (B) Epidermis of the adaxial surface and hypodermis (Hp). $\mathrm{Bar}=50 \mu \mathrm{m}$. (C) Epidermis of the abaxial surface. Bar $=50 \mu \mathrm{m}$. Abbreviations: SC, secreting channel; PP, palisade parenchyma; SP, spongy parenchyma; ( ), cuticular flanges; (*), stomatal ledges; (arrow), druse.

Figura 2 - Estrutura foliar de Clusia hilariana Schltdl., de plantas do tratamento-controle, em secção transversal. (A) Aspecto geral evidenciando o mesofilo dorsiventral. Barra $=100 \mu \mathrm{m}$. (B) Epiderme da face adaxial e hipoderme (Hp). Barra $=50 \mu \mathrm{m} .(C)$ Epiderme da face abaxial. Barra $=50 \mu \mathrm{m}$. Abreviaturas: SC, canal secretor; PP, parênquima paliçádico; SP, parênquima lacunoso; ( ), flanges cuticulares; (*), crista estomática; (seta), drusa. 


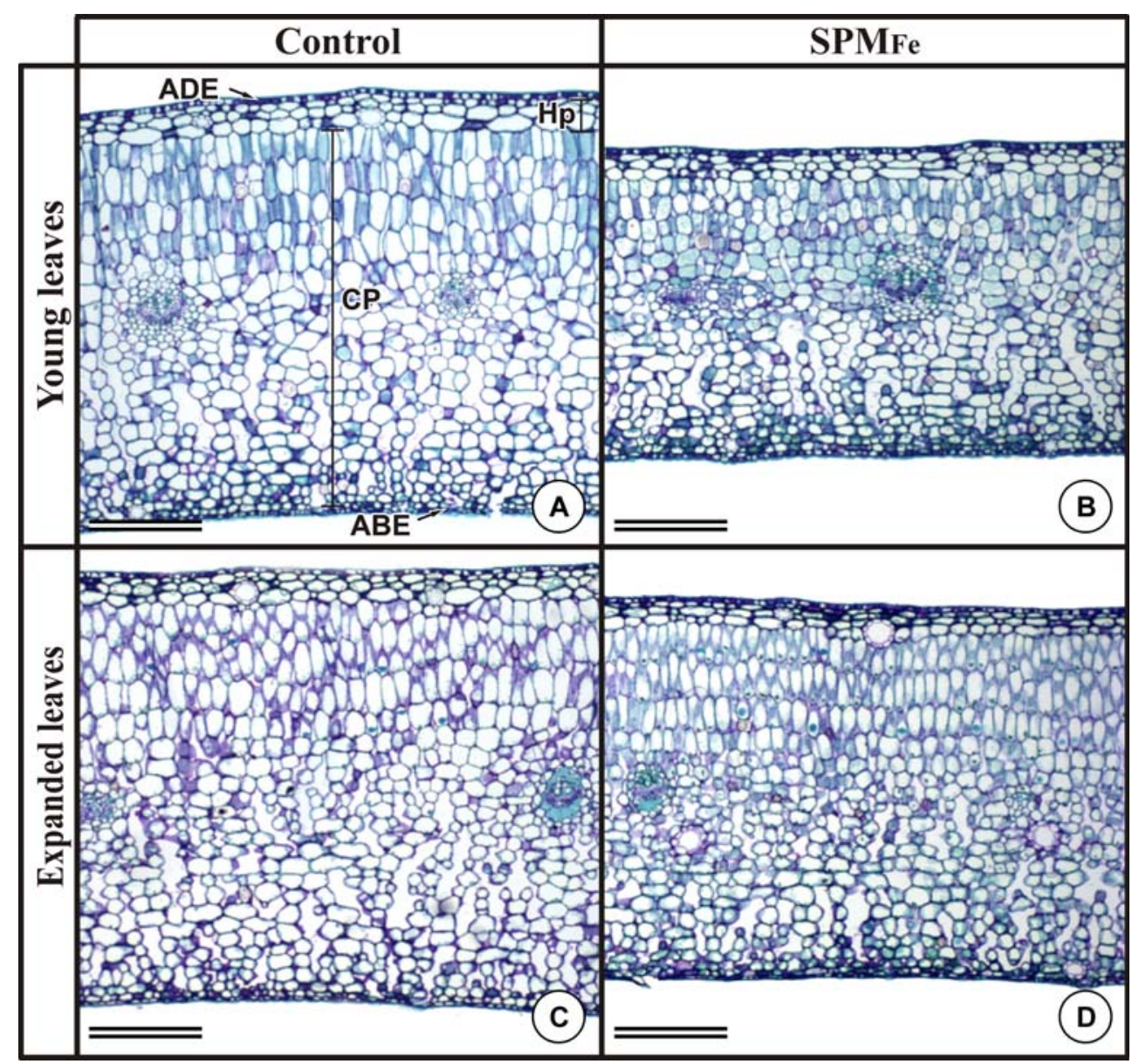

Figure 3 - Alterations in the leaf blade height of asymptomatic leaves of Clusia hilariana caused by the deposition of particulate iron. Transversal sections. Young leaves (first knot) (A, B). (A) Control treatment. (B) Treatment with iron. Smallest height of the leaf blade. Abbreviations: ABE, epidermis of the abaxial surface; ADE, epidermis of the adaxial surface; Hp, hypodermis; and CP, chlorophyll parenchyma. Bars $=100 \mu \mathrm{m}$.

Figura 3 - Alterações na espessura do limbo de folhas assintomáticas de Clusia hilariana causadas pela deposição de ferro particulado. Secções transversais. Folhas jovens (primeiro nó) (A, B). (A) Tratamento-controle. (B) Tratamento com ferro. Menor espessura da lâmina foliar. Folhas expandidas (quinto nó) $(C, D)$. (C) Tratamento-controle. (d) Tratamento com ferro. Menor espessura da lâmina foliar. Abreviaturas: ABE, epiderme da face abaxial; ADE, epiderme da face adaxial; Hp, hipoderme; e CP, parênquima clorofiliano. Barras $=100 \mu \mathrm{m}$.

\section{DISCUSSION}

The amount of particulate matter deposited on the plants in the simulation chamber was about three times lower than the amounts from the surrounding of the pelletizing industries observed by Lopes et al. (2000).

Although the leaf samples were collected from asymptomatic leaves, the observations made under a scanning electron microscope have shown significant injuries to the epidermis of the abaxial surface of young leaves, and on both surfaces of expanded leaves, making clear that the micromorphological alterations precede the visual injury (SANT'ANNASANTOS et al., 2012). We suggested the lack of injury on the adaxial surface of young leaves is related to the leaf architecture at this stage of development, that is, the adaxial surface is placed in parallel to the stem, exposing only the abaxial surface to the particulate deposition. As the leaves expand and 
Table 1 - Effect of the dosages of 0 (control) and $2.14 \mathrm{mg} . \mathrm{cm}^{-2}$.day ${ }^{-1}$ of iron particulate $\left(\mathrm{MSP}_{\mathrm{Fe}}\right.$ ) over the structural parameters of the leaf blade of young leaves (first knot) and totally expanded (fifth knot) of Clusia hilariana plants after 45 consecutive days of iron particulate deposition. ADE (height of the epidermis cells of the adaxial side); Hp (height of the hypodermis); CP (height of the chlorophyll parenchyma); ABE (height of the epidermis cells of the abaxial side); LB (height of the leaf blade).

Tabela 1 - Efeito das doses de 0 (controle) e 2,14 mg. $\mathrm{cm}^{-2}$. dia ${ }^{-1}$ de ferro particulado $\left(\mathrm{MSP}_{\mathrm{Fe}}\right.$ ) sobre os parâmetros estruturais da lâmina foliar de folhas jovens (primeiro nó) e totalmente expandidas (quinto nó) de plantas de Clusia hilariana após 45 dias consecutivos de deposição particulada de ferro. ADE (altura das células da epiderme da face adaxial); Hp (espessura da hipoderme); CP (espessura do parênquima clorofiliano); ABE (altura das células da epiderme da face abaxial); e LB (espessura do limbo).

\begin{tabular}{lccccr}
\hline \multicolumn{5}{c}{ Structural Parameters $(\mathrm{mm})$} \\
\hline Dosages & ADE & Hp & CP & ABE \\
\hline \multicolumn{5}{c}{ Young leaves } \\
\hline Control & $23.7 \pm 1.2^{\mathrm{a}}$ & $84.4 \pm 8.4^{\mathrm{a}}$ & $966.3 \pm 90.4^{\mathrm{a}}$ & $22.7 \pm 1.1^{\mathrm{a}}$ & $1100.0 \pm 95.5^{\mathrm{a}}$ \\
MSP $_{\mathrm{Fe}}$ & $22.3 \pm 0.5^{\mathrm{a}}$ & $61.5 \pm 5.5^{\mathrm{b}}$ & $703.1 \pm 44.6^{\mathrm{b}}$ & $21.7 \pm 1.2^{\mathrm{a}}$ & $809.4 \pm 54.3^{\mathrm{b}}$ \\
\hline \multicolumn{5}{c}{ Expanded leaves } \\
\hline Control & $18.9 \pm 0.5^{\mathrm{a}}$ & $79.0 \pm 2.8^{\mathrm{a}}$ & $1079.3 \pm 53.9^{\mathrm{a}}$ & $21.7 \pm 1.8^{\mathrm{a}}$ & $1195.1 \pm 57.3^{\mathrm{a}}$ \\
MSP $_{\mathrm{Fe}}$ & $20.2 \pm 1.0^{\mathrm{a}}$ & $66.3 \pm 2.7^{\mathrm{b}}$ & $907.9 \pm 45.8^{\mathrm{b}}$ & $20.4 \pm 1.8^{\mathrm{a}}$ & $1017.1 \pm 47.3^{\mathrm{b}}$ \\
\hline
\end{tabular}

Averages \pm standard error followed by the same letter vertically, within each fraction, did not differ significantly among each other, when compared by the Tukey test at a $5 \%$ probability.

Médias \pm erro-padrão seguidas pela mesma letra na vertical, dentro de cada fração, não diferem significativamente entre si, quando comparadas pelo teste de Tukey a $5 \%$ de probabilidade.

develop, both surfaces become subjected to the particulate deposition as they now are perpendicularly placed in relation to the stem.

Cuticle and epicuticular wax destructuring observed in Clusia hilariana seems a result from the abrasive effect of the particulate deposition on the leaf surface described by Eveling, 1986 and Riederer et al., 1994, and not by the toxic effect of the abundant iron being deposited. Similar injuries were observed in other plant species in answer to the deposition of particulate urban matter (PAL et al., 2002; RAÍ et al., 2010). The alterations in the epicuticular layer may compromise the survival of plant species, as the epicuticular layer is the first defensive wall against the environmental stress (PAL et al., 2002). The structure of the epicuticular wax are epidermic parameters and are related to differences in plant susceptibility or resistance to pollution (NEINHUIS; BARTHLOTT, 1998), being that micromorphology is a promising biomarker on the evaluation of stresses caused by atmospheric pollutants (SILVA et al. 2005; SANT'ANNA-SANTOS et al., 2006a,b).

The obstruction of the superstomatal chambers observed in this study for C. hilariana corroborates to the hypothesis proposed by Pereira et al., (2009) that the deposition of $\mathrm{SPM}_{\mathrm{Fe}}$ obliterates the stomata, limiting the stomatal conductance, causing an increase of the leaf temperature and the reduction of the transpiration rate in the leaves of plants of this species. Silva et al. (2006) have also suggested an internal temperature increase in leaves of Cordia verbenacea and Psidium guineense growing near a pelletizing industry, as probable effect of stomata obstruction.

As C. hilariana leaves are glabrous, this must have enabled a greater exposure of the leaves to the particulate deposition, maximizing the stomatal occlusion. The high trichome density can limit the exposure of the stomata to pollutants, avoiding injuries, and specially the stomatal occlusion (PALING et al., 2001).

The deformity and the occlusion of the stomata observed in the abaxial surface of C. hilariana leaves, possibly form a preferential entrance pathway for the pollutant. This observation corroborates with the data found by Silva et al., (2005) when characterizing the structural alterations caused by simulated acid rain in C. hilariana, in which the injury developed from the epidermis of the abaxial surface of the leaf. Stomata alterations caused by the deposition of particulate matter cause a physiological disturbance (FARMER, 1993; INOUE; REISSMANN, 1994; SILVAetal., 2006; PEREIRA et al., 2009), besides acting as an entrance pathway to the pollutant causing an increase in total concentration of metallic elements in the leaf tissues (GRANTZ et al., 2003).

Revista Árvore, Viçosa-MG, v.38, n.3, p.423-432, 2014 
The histological organization of C. hilariana was kept unaltered after 45 days of continuous exposure to $\mathrm{SPM}_{\mathrm{Fe}}$, presenting little structural injury. Even being a tolerant species, as shown in this work, the micromorphometric evaluations have contributed to the prognostic identification of injuries. Silva et al., (2005) had already considered this species to be tolerant to pollution, in comparison to Eugenia uniflora, after being subjected to simulated acid rain for 40 consecutive days.

The reduced height of asymptomatic leaves subjected to deposition of $\mathrm{SPM}_{\mathrm{Fe}}$ observed in C. hilariana can reflect the physiological effects of the particulate deposition as reported by Pereira et al., (2009). These authors have observed reduction in the photosynthetic rate, in the transport of electrons through the photosystem II, and excess of Fe in leaves of C. hilariana subjected to particulate iron ore. The lower conversion of energy in this species is possibly limiting the metabolism and development of the leaf tissues during the exposure period to the $\mathrm{SPM}_{\mathrm{Fe}}$, which therefore could be the cause of reduction on leaf tissues in response to the pollutant.

The degree of injury in the tissues can vary according to the age of the leaf in response to the pollutants (SILVA et al., 2000). In C. hilariana, the greater difference found for the leaf blade height of young leaves among the treatments suggest that they are more susceptible to the action of $\mathrm{SPM}_{\mathrm{Fe}}$ than the expanded leaves. However, further studies on the $\mathrm{Fe}$ levels in leaves at different developmental stages are necessary to evaluate whether there is a direct relation between the quantity of Fe and the degree of leaf injury or not.

The structural characteristics of the epidermis in C. hilariana, such as cuticle thickness and prominent cuticular flanges, and the epicuticular wax, were possibly the responsible factors for the tolerance of this tissue to the $\mathrm{SPM}_{\mathrm{Fe}}$ deposition, as observed in the studies with simulated acid rain by Silva et al., (2005).

Although no micromorphometric alterations were observed in the height of the epidermis in the evaluated C. hilariana leaves, the micromorphology analysis revealed several structural changes, such as the rupture of the epicuticular wax and the stomatal ledges. This reinforces the importance of comprehensive microscopic studies, combining the micromorphometry to the micromorphology, besides other structural analyses, aiming to identify parameters that are promising as biomarkers.

\section{CONCLUSION}

The alterations in the evaluated micromorphology and in the quantitative parameters in the leaf blade of Clusia hilariana were evident in the asymptomatic samples collecting, which demonstrate that these tools may be useful in the prognosis of injuries caused by iron particulate matter. The results achieved, along with physiological studies allow us to endow field studies that seek the use of this species in Biomonitoring programs.

\section{ACKNOWLEDGMENTS}

The authors thank the Parque Estadual Paulo César Vinha (ES) for supplying the seedlings, the Núcleo de Microscopia e Microanálise at the Universidade Federal de Viçosa (NMM-UFV), the Coordenação de Aperfeiçoamento de Pessoal de nível superior (CAPES) for the PNADB project (Programa Nacional de Apoio e Desenvolvimento da Botânica) and Conselho Nacional de Desenvolvimento Científico e Tecnológico (CNPq) for the financial support on the development of the Project (563335/2010-6 SISBIOTA Brasil) and for the Research Productivity Scholarships granted to L.C. Silva (309170/2012-5).

\section{REFERENCES}

ARNDT, U.; FLORES, F.; WEINSTEIN, L.

Efeitos do flúor sobre as plantas: diagnose de danos na vegetação do Brasil. Porto Alegre: Universidade Federal do Rio Grande do Sul, 1995. 155p.

BALASOORIYA, B. L. W. K. et al. Biomonitoring of urban habitat quality by anatomical and chemical leaf characteristics. Environmental Experimental of Botany, v.65, n.2-3, p.386-394, 2009.

CONAMA. Resolução do Conselho Nacional do meio ambiente (CONAMA) n003/90. 4.ed. Brasília: 1992. p.199-205. 
DIAS, A. T. C. et al. Aboveground biomass stock of native woodland on a Brazilian sandy coastal plain: estimates based on the dominant tree species. Forest Ecology and

Management, v.226, n.1, p.364-367, 2006.

EVELING, D. W. Scanning electron microscopy of damage by dust deposits to leaves and petals. Botanical Gazette, v.147, n.2, p.159-165, 1986.

FARMER, A. M. The effects of dust on vegetation - A review. Environmental Pollution, v.79, n.1, p.63-75, 1993.

GRANTZ, D. A.; GARNERB, J. H. B.; JOHNSON, D. W. Ecological effects of particulate matter. Environment International, v.29, n.2-3, p.213-239, 2003.

HIRANO, T.; KIYOTA, M.; AIGA, I. Physical effects of dust on leaf physiology of cucumber and kidney bean plants. Environmental Pollution, v.89, n.3, p.255-261, 1995.

HOAGLAND, D. R.; ARNON, D. I. The waterculture method for growing plants without soil. Berkeley: California Agricultural Experiment Station, 1950.31p.

INOUE, M. T.; REISSMANN, C. B. Efeitos da poluição na fotossíntese, dimensões da folha, deposição de particulados e conteúdo de ferro e cobre em alfeneiro (Ligustrum lucidum) da arborização de Curitiba, PR. Floresta, v.21, n.1/ 2, p.3-11, 1994.

JOHANSEN, D. A. Plant microtechnique. New York: McGraw-Hill, 1940. 523p.

KARDEL, F. et al. Assessing urban habitat quality based on specific leaf area and stomatal characteristics of Plantago lanceolata L. Environmental Pollution, v.158, n.3, p.788-794, 2010.

KARNOVSKY, M. J. A formaldehydeglutaraldehyde fixative of high osmolarity for use in electron microscopy. The Journal of Cell Biology, v.27, n.1, p.137-138, 1965.

KUKI, K. N.; OLIVA, M. A.; PEREIRA, E. G. Iron ore industry emissions as a potential ecological risk factor for tropical coastal vegetation. Environmental Manage, v.42, n.1, p.111-121, 2008a.
KUKI, K. N. et al. Effects of simulated deposition of acid mist and iron ore particulate matter on photosynthesis and the generation of oxidative stress in Schinus terebinthifolius Radii and Sophora tomentosa L. Science of The Total Environment, v.403, n.1-3, p.207-214, 2008b.

LIU, H. et al. Inûuence of iron plaque on uptake and accumulation of $\mathrm{Cd}$ by rice (Oryza sativa L.) seedlings grown in soil. Science of The Total Environment, v.394, n.2-3, p.361-368, 2008.

LOPES, S. A.; OLIVA, M. A.; MARTINEZ, C. A. Impacto das imissões de dióxido de enxofre e deposição de material particulado de ferro em espécies vegetais de restinga: avaliação ecofisiológica. In: ESPÍNDOLA, E. et al. (Ed.) Ecotoxicologia. São Carlos: RiMa Artes e Textos, 2000. p.53-71.

MESQUITA, G. L. et al. Atmospheric absorption of fluoride by cultivated species. leaf structural changes and plant growth. Water, Air, Soil Pollution, v.219, n.1-4, p.143-156, 2011.

NAIDOO, G.; CHIRKOOT, D. The effects of coal dust on photosynthetic performance of the mangrove, Avicennia marina in Richards Bay, South Africa. Environmental Pollution, v.127, n.3, p.359-366, 2004.

NEINHUIS, C.; BARTHLOTT, W. Seasonal changes of leaf surface contamination in beech, oak and ginkgo in relation to leaf micromorphology and wettability. New Phytologist, v.138, n.1, p.91-98, 1998.

NEVES, N. R. et al. Photosynthesis and oxidative stress in the restinga plant species Eugenia uniflora L. exposed to simulated acid rain and iron ore dust deposition: Potential use in environmental risk assessment. Science of The Total Environment, v.407, n.12, p.3740-3745, 2009.

O'BRIEN, T. P.; MCCULLY, M. E. The study of plant structure principles and selected methods. Melbourne: Termarcarphi Pty, 1981. $357 \mathrm{p}$.

OLALEYE, A. O. et al. Effect of toxic iron concentration on the growth of lowland rice. Journal of Plant Nutrition, v.24, n.3, p.441-457, 2001.

Revista Árvore, Viçosa-MG, v.38, n.3, p.423-432, 2014 
OLIVEIRA, C. R. M.; OLIVA, M. A.; PEREIRA, E. G. Efeito do material particulado de ferro no teor de pigmentos de Schinus terebinthifolius Raddi. Revista Brasileira de Biociências, v.5, n.2, p.681-683, 2007.

PAL, A. et al. Do leaf surface characters play a role in plant resistance to auto-exhaust pollution? Flora, v.197, n.1, p.47-55, 2002.

PALING, E. I. et al. The effects of iron ore dust on mangroves in Western Australia: lack evidence for stomatal damage. Wetlands Ecology and Management, v.9, n.5, p.363$370,2001$.

PEREIRA, E. G. et al. Photosynthetic changes and oxidative stress caused by iron ore dust deposition in the tropical CAM tree Clusia hilariana. Trees, v.23, n.2, p.277-285, 2009.

RAÍ, A. et al. Leaf surface structure alterations due to particulate pollution in some common plants. Environmentalist, v.30, n.1, p.18-23, 2010.

RIEDERER, M. et al. Air pollutants and the cuticle: implications for plant physiology. In: PERCY, K. E. et al. (Ed.) Air pollutants and the leaf cuticle. Berlin: Springer-Verlag, 1994. p.107-111.

SANT'ANNA-SANTOS, B. F. et al. Effects of simulated acid rain on the foliar micromorphology and anatomy of tree tropical species. Environmental and

Experimental Botany, v.58, n. 1, p. 158-168, 2006a.

SANT'ANNA-SANTOS, B. F. et al. Effects of simulated acid rain on leaf anatomy and micromorphology of Genipa americana L. (Rubiaceae). Brazilian Archives of Biology and Technology, v.49, n.2, p.313321, 2006b.
SANT'ANNA-SANTOS, B. F. et al. Utilização de parâmetros morfoanatômicos na análise da fitotoxidez do flúor em folhas de Magnolia ovata (A. St.-Hil.) Spreng. (Magnoliaceae). Revista Árvore, v.31, n.4, p.761-771, 2007.

SANT'ANNA-SANTOS, B. F. et al. Diagnostic and prognostic characteristics of phytotoxicity caused by fluoride on Spondias dulcis Forst. F. (Anacardiaceae). Anais da Academia Brasileira de Ciências, v.84, n.3, p.689702, 2012.

SILVA, L. C. et al. Flúor em chuva simulada: sintomatologia e efeitos sobre a estrutura foliar e o crescimento de plantas arbóreas. Revista Brasileira de Botânica, v.23, n.4, p.383391,2000

SILVA, L. C. et al. Micromorphological and anatomical alterations caused by simulated acid rain in restinga plants: Eugenia uniflora and Clusia hilariana. Water, Air, \& Soil Pollution, v.168, n.1, p.129-143, 2005.

SILVA, L. C. et al. Responses of restinga plant species to pollution from an iron pelletization factory. Water, Air, \& Soil Pollution, v.175, n.1, p.241-256, 2006.

SIQUEIRA-SILVA, A. I. et al. Iron plaque formation and morphoanatomy of roots from species of restinga subjected to excess iron. Ecotoxicology and Environmental Safety, v.78, n.1, p.265-275, 2012.

SILVEIRA, V. C. et al. Influence of iron on mineral status of two rice (Oryza sativa L.) cultivars. Brazilian Journal of Plant Physiology, v.19, n.2, p.127-139, 2007.

SODA, C. et al. Impacts of urban levels of ozone on Pinus halepensis foliage.

Environmental and Experimental Botany, v.44, n.1, p.69-82, 2000. 